\title{
Geographies of external voting: the Tunisian elections abroad since the 2011 Uprising
}

Thibaut Jaulin

\author{
Correspondence: \\ thibaut.jaulin@sciencespo.fr \\ Marie Curie Fellow, CERI/Sciences \\ Po, Paris, France
}

\begin{abstract}
This contribution draws on the developing literature on the participation of citizens' abroad in elections of their country of origin. It looks at Tunisia as a case study. Although it focuses on a single case study, this paper is comparative to the extent that it puts the case of Tunisia in perspective with other cases from the literature, and that it discusses the influence of different settings on the voter turnout and the voting behaviour of the Tunisians abroad. By doing so, it shows how Tunisian specificities contribute to academic discussions on the diffusion of new citizenship norms in the age of globalization and on the extent to which migration contributes to political change in labour sending countries.

The paper first explores the adoption of external voting provisions by the former Tunisian president Zine El Abidine Ben Ali as soon as 1988, and the extension of external voting rights after the 2011 Uprising. The paper further adopts a geographic, diachronic, and multi-level approach to analyse the voter turnout and the voting behaviour among the Tunisians abroad since 2011. Results first show that the adoption and implementation of external voting in Tunisia is closely articulated to domestic processes of political change, regardless of the type of regime (authoritarian or democratic). Furthermore, results show that the voting behaviour of the Tunisians abroad follows the same trends than their Tunisian counterparts, but that it varies significantly depending on their place of residence (country, city, and neighbourhood). Such observation challenges the idea according to which migrants socialised with liberal values in Western societies tend to promote such values in their homeland. In contrast, this paper argues that the voter turnout and the voting behaviour in external elections depend on pre-migration variables and on the local context in which migrants are embedded.
\end{abstract}

Keywords: Migration, Diaspora, Transnationalism, Democratization, Arab spring, Election, Voting behaviour, External voting

\section{Background}

In the last decade, external voting has gained growing attention among scholars, in particular within transnational studies, as the number of countries that have granted voting rights to their citizens abroad soared from 31 in 1991 to about 120 in 2010 (Lafleur, 2013).

The literature on external voting first includes normative political theory, which discusses if and under which conditions citizens abroad should be entitled to vote. Opponents to external voting usually point at the threat to national sovereignty, in particular when diaspora outnumbers domestic population; the high costs of organizing elections abroad; 
and the greater risks of fraud (Lopez-Guerra, 2005; Rubio-Marin, 2006). In contrast, external voting supporters claim that voting rights should be granted to all citizens independently of their place of residence. Bauböck (2007) further argues that the diffusion of external voting actually illustrates the transformations of the concept of citizenship in the age of globalization. He considers that external voting echoes the extension of the franchise to foreign residents (usually in local elections) as both call into question the republican conception of citizenship according to which membership in the political community and permanent residency in the country are both required to be entitled to vote.

The literature on external voting further comprises a growing number of research studies, which question the why and how States enfranchise their citizens abroad, and which explore the latter's voting behaviour and voting practices.

The adoption of external voting in labour sending countries is commonly viewed as a way to foster migrants' remittances, which frequently represent a major source of foreign currencies. However, external voting is not confined to labour-sending countries and no correlation has been found between the adoption of external voting and the share of remittances in the GDP or the relative size of the population abroad (Collyer \& Vathi, 2007). Although the economic dependency on migration does not seem to explain the diffusion of external voting, integration in the global economy is typically one of the arguments in favour of external voting (Lafleur, 2013).

Another reason that commonly explains the diffusion of external voting is the growing claims for voting rights from migrants' organizations, in particular in context of democratic transition (Rhodes \& Harutyunyan, 2010). However, the influence of migrants' organizations, some of which barely consist in "four guys and a fax machine" (Rowe, 2001), should not be overestimated. More importantly, external voting is not confined to democracies, as shown by several examples, including Algeria, Morocco, and Tunisia in the 1970s and 1980s (Brand, 2010). Overall, the adoption of external voting provisions appears to be inseparable from broader domestic political processes, from competition between political parties to institutional reforms (e.g. electoral or constitutional reform, regionalization, etc.) (Lafleur, 2015).

Domestic politics also matter when it comes to understand the heterogeneous forms of implementation of external voting. Voting procedures and voting systems vary greatly from one country to another (Collyer, 2014; International IDEA, 2007; Lafleur, 2013). For example, external voting can be restricted depending one the country of residence or the length of stay abroad. Moreover, practicalities to cast a ballot (postal/electronic voting, voting in person abroad) may deter electoral participation if associated with very high "costs" (e.g.: long journey to the nearest polling station, tortuous administrative procedures). Finally, how ballots are counted (in domestic or in overseas constituencies) has a great impact on the potential to influence electoral outcomes. To sum up, genuine political participation and representation for the citizens abroad largely depend on the voting procedures and the voting system.

The literature on external voting eventually includes research studies that apply electoral sociology methods to understand the patterns and dynamics of external voting behaviour. The results suggest that political preferences among the electors abroad are strongly shaped prior departure, rather than resulting from their experience abroad. Lafleur and Sanchez Dominguez (2016), who look at external voting among Bolivians 
in South America, North America, and Europe, conclude that the migration experiences influences to a certain extent perceptions of homeland politics, but that political preferences are mostly shaped prior to departure. ${ }^{1}$ Similarly, Ahmadov and Sasse (2015) find that political preferences among Ukrainians and Poles abroad are strongly predicted by their regional background. Eventually, Dedieu, Chauvet, Gubert, Mesplé-Somps, and Smith (2013) argue that the political landscape of the Senegalese diaspora reflect the homeland's political and ethnic divisions.

Such conclusions suggest to reflecting critically on the notion of political remittances ${ }^{2}$ as a tool to promote democracy and civic participation in labour sending countries. For example, it challenges Mahmoud, Rapoport, Steinmayr, and Trebesch (2013) who identify a robust and negative effect of emigration to the West on the votes for the Communist Party in the Moldovan elections (2009-10) and who argue: "exit and voice can be complementary in bringing political change and jointly contribute to the global diffusion of democracy" (Mahmoud et al., 2013:28).

To sum up, the developing literature on external voting first suggests to exploring how the worldwide diffusion of external voting articulates to domestic political processes. Furthermore, it challenges the idea according to which migrants socialised with liberal values in Western societies tend to promote such values in their homeland (Koinova, 2010).

Such questions echoes issues addressed by the literature on Tunisian transnational politics. ${ }^{3}$ Brand (2006) explores the relationship between the development of diaspora policies in Tunisia and the broader process of regime formation and consolidation during the presidencies of Habib Bourguiba (1957-1987) and Zine el-Abidine Ben Ali (1987-2011). She especially shows how the development of a very large consular network and of statesponsored migrants' association, so called Amicales des travailleurs tunisiens, aimed at monitoring political activities among the Tunisian migrants. Moreover, research studies on transnational political engagement among the Tunisians abroad tend to discuss the extent to which political dynamics abroad simply reflect political dynamics at home or rather depend on specific constraints and challenges (Geisser, 2012). For example, Ayari (2007-2008) explains how the French context has shaped the forms of political engagement of members of the Islamist party EnNahda in France, and their relations with other opposition parties, ${ }^{4}$ in contrast with their counterparts based in Italy or in the United Kingdom.

This contribution looks at Tunisia as a case study to explore the diffusion of new citizenship norms in the age of globalization and to discuss the extent to which migration contributes to political change in labour sending countries. It first discusses methodological challenges faced by this paper. Following a brief overview of Tunisian migration trends, it looks at the adoption of external voting provisions by the former Tunisian president, Zine El Abidine Ben Ali, and the extension of external voting rights after the 2011 Uprising. The paper eventually focuses on the voter turnout and the voting behaviour of the Tunisians abroad since 2011.

\section{Methodology}

Although this paper focuses on a single case study, it is comparative in its approach (Bloemraad, 2013). Firstly, it puts the case of Tunisia in perspective with other cases from the literature. Secondly, it discusses the influence of different settingson the voting behaviour of the Tunisians abroad. 
Three main reasons justify the choice of Tunisia as a case study. First, the adoption of external voting is the result of a mixed process of political liberalization and authoritarian consolidation. External voting was first adopted in 1988 by Zine el-Abidine Ben Ali, one year after his coup against Habib Bourguiba, and was subsequently implanted in 1989 in a context of political liberalization. However, elections that followed the authoritarian turn of his regime in the early 1990s were characterized by massive frauds. Then, after the 2011 Uprising, the transitional authority in charge of leading the country "from the revolution to the election" gave a new impetus to external voting. Tunisia now allows direct parliamentary representation for its citizens abroad (as only thirteen other countries worldwide) and provides a number of overseas representatives that is proportionate to the (estimated) number of Tunisians abroad, which is unique in the world (Collyer, 2014). Third, the voter turnout among the Tunisians abroad is relatively important since 2011, especially in regard with the low voter turnout that characterizes external elections worldwide (International IDEA, 2007).

This paper builds on two main sources. First, interviews with Tunisians officials and with stakeholders from the Tunisian community in France conducted from 2012 to 2014 in Tunis, France and Italy. Information gathered during these interviews have been key to clarify the conditions of the adoption and implementation of external voting after 2011, in particular the pitfalls and drawbacks of the process of registration on the electoral rolls. Electoral data provided by the Tunisian body in charge organizing the elections (ISIE in French) since 2011 represent the second main source of information for this paper. Some of these data are available on-line, ${ }^{5}$ mostly under the form of polling stations' official statements of the vote, and others have been collected by the author.

This paper adopts a diachronic, geographic, multilevel approach to analyse these data. It looks at two elections for the national legislature since the Uprising (the Constituent Assembly in October 2011 and the Parliament in October 2014) and it compares the voter turnout and the voting behaviour at home and abroad, in each overseas constituency, and at the district level in the French region of Île-de-France (Paris and suburbs). Such approach faces three main methodological challenges.

First, reliable and detailed statistical data on the Tunisian population abroad are lacking. Migration statistics typically vary depending on who counts (the country of origin or residence) and who is counted (criteria to define who is a migrant) (Fargues, 2005). For example, the number of Tunisians abroad varies from 643,212 (in 2013) according to the United Nation Department for Economic and Social Affairs (UNDESA, 2010) to 1,222,533 (in 2012) according to the (Tunisian) Office des Tunisiens à l'étranger (OTE, 2012) (OTE in French). ${ }^{6}$ Added to the lack of detailed demographic and socioeconomic information, the above forbid testing research hypothesis through correlations. Moreover, the estimation of the voter turnout abroad suffer from serious flaws due to the inconsistencies of the registration rolls in the overseas constituencies, as explained below (see Boom and bust of the voter turnout since the Uprising). As a consequence, this paper focuses on variations of the absolute number of ballots from one election to the other, and relies on the voting age population abroad to estimate the voter turnout. More generally, it consists in a rigorous descriptive analysis of the voter turnout and the voting behaviour of the Tunisians abroad since 2011, with the aim of addressing new research questions. 
The second challenge has to do multilevel analysis. Electors abroad, unlike electors at home, are often required to register and to vote in a polling station quite distant from their place of residence, especially when the migrant community is scattered in a vast territory in which few polling stations are available. In the case of Tunisia, in constrast, the ISIE disseminated numerous polling stations in each large urban centres of Europe, North America, and the Gulf that host large Tunisian migrant communities.

Two reasons explain the choice of the region of Île-de-France (Paris and suburbs) to explore the voting behaviour of Tunisians abroad at the local level: 1) four-fifths of the voters of the constituency of France 1 casted their ballot in the Île-de-France, and 2) polling stations were set up in about twenty different locations, both in Tunisian and French public buildings. Although Tunisian electors in the Île-de-France were free to register/vote in the polling station of their choice, this paper assumes for the sake of the analysis that most voted in a polling station close to their place of residence. As a matter of fact, the districts of Paris and Seine-Saint-Denis, where most Tunisian migrants reside (Institut national de la statistique et des études économiques INSEE, 2012), have concentrated the largest share of the votes.

The third methodological challenge has to do with the extensive transformations of the Tunisian political landscape from 2011 to 2014. During this period, new political parties were created and other disappeared, electoral alliances were forged and dissolved, and resignations of party representatives were frequent. For example, two among the six parties that ranked first in the 2011 election disappeared in the following year, ${ }^{7}$ one went through profound internal changes, ${ }^{8}$ and two obtained very disappointing results in 2014. ${ }^{9}$ Eventually, the political landscape evolved from a multiparty system to a (quasi) two-party system with the creation of Nidaa Tounes, which gathered most of the opponents to the Islamist party EnNahda and which eventually won the 2014 elections.

Accordingly, the following mostly focuses on the evolution of the results of EnNahda from 2011 to 2014, and compares it with that of Nidaa Tounes in 2014. However, I am aware that focusing on EnNahda and Nidaa Tounes tends to reify the opposition between secularism and Islamism. I should thus insist that such opposition does not adequately reflect the Tunisian parties' complex positioning regarding issues such as the nature and the role of the State, the meaning of national identity, and the basic aims of economic, social and foreign policies (Ben Mami, 2013; Ferjani, 2012). ${ }^{10}$

\section{Results and discussion}

The following first recalls how Tunisia evolved from a labour sending country to a country with a diaspora. Then it analyses the reasons for adopting external voting provisions in 1989, and the characteristics of the voting system set in place after 2011. It further discusses the sharp decrease of the number of voters abroad from 2011 to 2014, and it eventually looks at the voting behaviour of the Tunisians abroad at the global level, at the country level, and at the local level.

\section{Tunisia: from labour migration to diaspora communities}

The first major wave of labour migration from Tunisia started in the 1960s, after the country's independence in 1956, due to high unemployment rates at home and high demand for unskilled labour in Western Europe. Tunisian migrants, similarly to 
Algerians' and Moroccans', mostly migrated to France, the former colonial power. At first, Tunisian labourers who sought to work in France travelled with a tourist visa and asked for long-term residence permit after being recruited. Starting from 1963, Tunisian and French governments actively collaborated to select, convey and put at work Tunisian labourers. Controlled labour migration gradually became the main trend. From the mid-1960s to the mid-1970s, the number of Tunisian migrants in France was multiplied by three, to reach 150,000 (official ${ }^{11}$ ). Tunisian migrants in France concentrated in the region of Paris (Ile-de-France), Marseille and Nice (Provence-Alpes-Côte d'Azure), and Lyon (Rhône-Alpes) (Oueslati, 2009; Simon, 1979).

The Western European states' decision to stop labour migration, following the oilcrisis in 1973-1974, greatly impacted Tunisian migration trends and patterns. Most migrants in Western Europe settled in their host countries and benefited from family reunification schemes. Demographic and social characteristics of migrant communities gradually changed. In parallel, growing demand for labour in Arab oil-producing countries attracted large flows of Arab and (then) Asian migrants. In addition to the Arab Gulf, which has continuously attracted Tunisian businessmen and professionals (teachers, doctors, nurses), Libya has been a major destination country for Tunisian migrants, until the Libyan Civil War broke up in 2011. It is noteworthy that poor diplomatic relations between Tunisia and Libya in the 1980s and 1990s resulted in fluctuating Libyan policies toward Tunisians migrants: from open door to massive expulsions (Brédeloup \& Pliez, 2011).

Since the late 1990s, Tunisia has witnessed an upsurge of migration due to the growing demand of labour and lack of employment opportunities, is particular among university graduate (Fargues, 2012). This second migration wave is characterized by greater destination diversity. During this period, Italy has become the second largest destination country for Tunisian migrants, after France, and North America has attracted significant numbers of (mostly) highly skilled Tunisian migrants (CARIM, 2010). As mentionned above, the number of Tunisians abroad is estimated to 1.2 million according to Tunisian statistics and to about half of this figure according to destination countries' statistics. However, beyond such gap, most sources converge to estimate that France hosts more than a half of the Tunisians abroad, Italy about $15 \%$, and Germany, Libya, ${ }^{12}$ the Arab Gulf and North America about $5 \%$ each.

\section{External voting: a legacy of the regime of Ben Ali}

The extension of the franchise to the Tunisian abroad is a legacy of the regime of Zine al-Abidine Ben Ali. Such extension was part of a new policy set in place after Ben Ali seized power in 1987 with the aim to foster economic, social and cultural ties with the Tunisians abroad. In addition to granting the right to vote abroad for presidential elections, Ben Ali simultaneously created the Office of the Tunisians Abroad in 1988 and nominated new consular staff, so called social attachés, to provide social services to the Tunisians abroad. The official denomination Tunisian Labourers Abroad (TTE in French) was also changed for Tunisian Living Abroad (TRE in French).

Tunisians abroad first experienced external voting on the occasion of the 1989 presidential election, which took place in a context of political liberalization, although it turned into a plebiscite for Ben Ali. 75,000 casted a ballot from abroad, out of a Tunisian population abroad estimated to 400,000 (including children). The number of voter shrank 
in the following elections as voting progressively turned into a sign of allegiance to the regime due the generalization of election fraud and the authoritarian turn of the regime (Brand, 2010). However, one should acknowledge the legacy of Ben Ali's regime, which largely contributed to institutionalize external voting. For example, it is noteworthy that the ISIE barely modified the map of the 450 polling stations abroad as it was set up by Ben Ali. In addition to Tunisian consulates and cultural centres, polling stations are found in city halls and public schools and gymnasiums, which are usually given for free by the host country's local authorities. Such apparatus obviously contributes to increase the voter turnout.

The institutionalization of external voting can also explain the lack of serious opposition against the participation of the Tunisian abroad in the elections since 2011. In the aftermath of the Uprising, the Tunisian associations abroad launched a large gathering (Assises de l'immigration tunisienne) and drafted series of claims in a Cahier de doléances. Such claims included the right to vote from abroad in both presidential and legislative elections, fair representation of the Tunisians abroad in the parliament, and the right to be elected, including for dual citizens. The body in charge of the political transition immediately responded favourably (Lieckefett, 2012; Chouikha, 2012).

The new electoral law allocated 18 seats to Tunisians abroad, out of 217, on a basis of one seat for 40,000 electors, both at home and abroad. These seats were distributed in six overseas constituencies: France 1 and France $2^{13}$ (5 seats each), Italy ( 3 seats), Germany (1 seat), Americas/rest of Europe ( 2 seats), Arab countries/rest of the world (2 seats). However, as a consequence of the sharp decrease of the number of voters from 2011 to 2014 (see below), the Tunisians abroad are currently overrepresented in the Parliament. ${ }^{14}$ Such imbalance poses the risk of undermining the legitimacy of the overseas representative and transforming overseas constituencies into political stronghold in the hand of local clientele.

\section{Boom and bust of the voter turnout since the Uprising}

In October 2011, about 210,000 Tunisians abroad voted to elect the representatives of the Constituent Assembly. Such figure is exceptionally high comparatively to countries where the migrant population is much larger and the number of voters abroad much smaller, such as Mexico (International IDEA, 2007). However, three year later, the number of voters abroad for the parliamentary election decreased by half.

Table 1 presents the evolution of the number of voters in each overseas constituency and in Tunisia. It shows that that decline of the number of voters form from 2011 to 2014 is much more limited in Tunisia than abroad. Such evolution can be the result of a lack of interest of the electors abroad for homeland politics after a short-lived awareness period in the context of the Arab Spring. However, this hypothesis fails to grasp the impact of voting procedures.

In 2011, the result of the enrolment campaign launched by the ISIE before the election was disappointing. Such failure seemed all the more serious as it called into question the citizens' confidence the democratic process. As a consequence, the ISIE extended the delay to register, facilitated the registration procedures, enrolled "automatically" those electors who had not done so "voluntarily", and eventually decided that anyone would be entitled to vote even if not registered on the electoral roll, providing that he/she had a Tunisian ID or passport. ${ }^{15}$ 
Table 1 Ballots, electoral rolls, and voting age population in the Tunisian overseas constituencies

\begin{tabular}{|c|c|c|c|c|c|c|c|}
\hline \multirow[t]{2}{*}{ Constituency } & \multirow[t]{2}{*}{ Year } & \multicolumn{2}{|l|}{ Ballots } & \multicolumn{2}{|c|}{ Registered electors } & \multicolumn{2}{|c|}{ Voting age pop. (2011) } \\
\hline & & Number & $\begin{array}{l}\text { Difference } \\
2011 / 2015 \\
\end{array}$ & Number & $\begin{array}{l}\text { Difference } \\
2011 / 2015 \\
\end{array}$ & Voting age pop. & Turnout \\
\hline \multirow[t]{2}{*}{ France 1} & 2011 & 68,400 & $-42.6 \%$ & 93,978 & $-15.0 \%$ & 194,968 & $35.1 \%$ \\
\hline & 2014 & 39,233 & & 79,925 & & & $20.1 \%$ \\
\hline \multirow[t]{2}{*}{ France 2} & 2011 & 56,364 & $-44.7 \%$ & 89,757 & $27.2 \%$ & 239,408 & $23.5 \%$ \\
\hline & 2014 & 31,174 & & 114,192 & & & $13.0 \%$ \\
\hline \multirow[t]{2}{*}{ Italy } & 2011 & 23,328 & $-69.3 \%$ & 67,364 & $-19.7 \%$ & 102,663 & $22.7 \%$ \\
\hline & 2014 & 7,162 & & 54,072 & & & $7.0 \%$ \\
\hline \multirow[t]{2}{*}{ Germany } & 2011 & 13,486 & $-45.1 \%$ & 37,065 & $-55.1 \%$ & 63,429 & $21.3 \%$ \\
\hline & 2014 & 7,407 & & 16,650 & & & $11.7 \%$ \\
\hline \multirow[t]{2}{*}{ Americas/rest Europe } & 2011 & 28,371 & $-44.8 \%$ & 54,073 & $-3.7 \%$ & 72,162 & $39.3 \%$ \\
\hline & 2014 & 15,648 & & 52,065 & & & $21.7 \%$ \\
\hline \multirow[t]{2}{*}{ Arab countries/rest world } & 2011 & 19,746 & $-38.4 \%$ & 18,307 & $76.3 \%$ & 48,966 & $40.3 \%$ \\
\hline & 2014 & 12,158 & & 32,269 & & & $24.8 \%$ \\
\hline \multirow[t]{2}{*}{ Total abroad } & 2011 & 209,695 & $-46.2 \%$ & 360,544 & $-3.2 \%$ & 721,596 & $29.1 \%$ \\
\hline & 2014 & 112,782 & & 349,173 & & & $15.6 \%$ \\
\hline \multirow[t]{2}{*}{ Tunisia } & 2011 & $4,096,631$ & $-15.4 \%$ & $4,123,602$ & $17.5 \%$ & $7,993,924$ & $51.2 \%$ \\
\hline & 2014 & $3,464,989$ & & $4,847,292$ & & & $43.3 \%$ \\
\hline
\end{tabular}

Source: ISIE, compiled by the author

Such decisions contributed to increase the number of voters (Verdeil, 2012). However, the electoral law adopted in 2013 requires all citizens to register in order to be entitled to vote, which prevented many electors to vote in 2014, especially abroad due to the lack of efficient registration campaign and greater hurdles. For example, electoral observation reports (Mourakiboun, 2014) and the author's observations in Paris show that many electors renounced to vote because they could not find their name of the electoral rolls due to flaws in the registration process. To sum up, the above suggests that electors abroad renounce to exercise their voting rights when the "costs" of voting are too high, like electors at home (Braconnier \& Dormagen, 2007), and that restrictive and/or flawed voting procedures have a greater impact abroad than at home.

Moreover, the fact that registration procedures were modified on several occasions before the 2011 election and that it changed again in 2014 renders the electoral rolls quite unreliable to estimate the voter turnout, in particular in the overseas constituencies. For example, it is common to found mistakes and overlaps in the polling stations' official statements in 2011 regarding how many electors from each roll ("voluntary", "automatic", "complementary") casted a ballot. Moreover, local branches of the ISIE in the overseas constituencies have not applied the same procedures to register the electors in 2014. While some branches registered only those electors who actually showed up, others also included names of electors registered "automatically" in $2011 .{ }^{16}$ This explains why the evolution of the number of ballots from 2011 to 2014 is disconnected from the evolution of the number of registered electors in some constituencies (Table 1).

Due to such inaccuracies, the following relies on the voting age population abroad ${ }^{17}$ to estimate the voter turnout. Turning to each overseas constituency, two groups of countries can be identified: Germany, Italy, and France 2, where the turnout is sharply 
and constantly below the average; and France 1, North America/rest of Europe, and Arab countries/rest of the world, where the turnout is above. Such observation suggests that the turnout tend to be higher in countries that favour high skilled migration, such as Canada and the United States, or migration of semi-skilled professionals, such as the Arab Gulf (Sliman \& Khlif, 2009). In contrast, the turnout tends to be lower in Italy, which has massively attracted low skilled migrants working for low paid jobs since the 1990s. Similarly, the gap between France 1 and France 2 could be explained by different internal migration patterns, with Paris attracting more students and skilled migrants than other French cities. Such results suggest that socioeconomic variables have an impact on the voter turnout abroad, as it is the case at home (Gana, Van Hamme, \& Ben Rebah, 2012).

\section{Slotted transnational political spaces}

The last section consists in a comparison of the results of the main Tunisian political parties in 2011 and in 2014. It looks first at the results at home and abroad, then in the overseas constituencies, and eventually in the eight districts of the French region of Île-de-France (Paris and suburbs), which concentrates the bulk of the electorate of the constituency of France 1.

Table 2 first shows that the results of the main parties are quite similar at home and abroad, and that they follow the same trend independently of the result of the election. For example, the Islamist party EnNahda has almost the same score at home and abroad both in 2011, when it wins the election, and in 2014 when it looses. Correspondingly, the score of Nidaa Tounes, the winner of the 2014 election, are quite analogous at home and abroad.

Such similarity contrasts with other case studies. For example, political preferences among the Romanians abroad are quite different from that of the Romanians in Romania, and are characterized by entrenched preferences for liberal parties (Burean, 2011). In the case of Tunisia, transnational political preferences are not fixed once and for all. Tunisians abroad can change their vote from election to another. The general hostility toward Ben Ali's regime after the Uprising and a common inclination for parties that suffered the most from political oppression, both at home and abroad, can explain EnNahda's result in 2011. Conversely, the overall decline of EnNahda

Table 2 Results of the main parties at home and abroad in 2011 and in 2014

\begin{tabular}{|c|c|c|c|c|c|c|c|c|c|}
\hline & \multirow{2}{*}{\multicolumn{2}{|c|}{$\frac{\text { Abroad }}{2,011}$}} & \multicolumn{2}{|l|}{ Tunisia } & & \multirow{2}{*}{\multicolumn{2}{|c|}{$\frac{\text { Abroad }}{2,014}$}} & \multicolumn{2}{|l|}{ Tunisia } \\
\hline & & & \multirow[b]{2}{*}{ Ballots } & \multirow[b]{2}{*}{ Seats } & & & & & \\
\hline & Ballots & Seats & & & & Ballots & Seats & Ballots & Seats \\
\hline EnNahda & $37.6 \%$ & 9 & $37.0 \%$ & 80 & Nidaa t. & $40.2 \%$ & 8 & $37.46 \%$ & 78 \\
\hline CPR & $11.0 \%$ & 4 & $8.5 \%$ & 25 & EnNahda & $30.3 \%$ & 8 & $27.70 \%$ & 61 \\
\hline AlAridha & $6.6 \%$ & 2 & $7.0 \%$ & 18 & UPL & $1.4 \%$ & 0 & $4.13 \%$ & 16 \\
\hline Ettakatol & $9.7 \%$ & 2 & $6.9 \%$ & 16 & $\mathrm{FP}$ & $3.9 \%$ & 0 & $3.65 \%$ & 15 \\
\hline PDP & $7.3 \%$ & 0 & $3.8 \%$ & 4 & Afek t. & $3.9 \%$ & 1 & $2.99 \%$ & 7 \\
\hline PDM & $6.2 \%$ & 1 & $2.6 \%$ & 24 & CPR & $5.1 \%$ & 0 & $2.04 \%$ & 4 \\
\hline Others & $21.6 \%$ & 0 & $34.3 \%$ & 32 & Others & $10.0 \%$ & 1 & $22.03 \%$ & 18 \\
\hline Total & 217,945 & 18 & $3,846,204$ & 199 & Total & 112,031 & 18 & $3,296,139$ & 199 \\
\hline
\end{tabular}

Source: ISIE, compiled by the author 
suggests a general dissatisfaction, both at home and abroad, in regard with the party's achievements from 2011 to 2014. In other words, Tunisians abroad (at least those who vote) appear to be closely connected to their homeland and fully aware of its politics.

A closer look at Table 2 however reveals different voting patterns between the Tunisians at home and abroad when it comes to middle-size and small-size parties. First, medium-size parties usually obtain better results abroad. In 2011, four out of five parties that ranked behind the winner of the election (EnNahda) had much better results abroad than at home (from three to four points). Similarly, in 2014, three out of four parties that ranked behind Nidaa Tounes and EnNahda had better results abroad than at home (from one to three points). Conversely, small size parties ("others" in Table 2) have better results at home than abroad. In other words, the dispersion of the vote is much greater in Tunisia than abroad.

One reason that explains such trends is the lack of financial and human resources within small-size parties. As a matter of fact, most have not presented candidates abroad and those who did rarely campaigned abroad. As a consequence, voters abroad dissatisfied with the two main political parties (Nidaa Tounes and EnNahda in 2014) may have tended to vote for middle-size parties, rather than small-size parties. The example of community leaders who presented an independent list and who benefited from a quite large support in specific locations due to the exceptional backing of local community stakeholders ${ }^{18}$ tends to confirm this hypothesis. To sum up, this table suggests that transnational voting behaviour simultaneously involves national and local constraints and dynamics.

The second level of analysis looks at the overseas constituencies. The following maps are tailored to fit the heterogeneous size and shape of the overseas constituencies and the unequal dispersion of the Tunisians abroad. Each map is thus made of two maps: a map of Western Europe for the constituencies of France 1 and 2, Italy, and Germany, and a World map for the constituencies of Americas/rest of Europe, and Arab countries/rest of the are represented. Furthermore, circles of different sizes represent the total number of voters in each constituency (or in each district for the region of Île-deFrance).

Maps 1 and 2 compare the results of EnNahda in 2011 and 2014. The results show that voting trends in each constituency are consistent from one election to the other, although the result of the election changes. For example, EnNahda's results are systematically above the average in the constituencies of Italy, Germany and Arab countries/rest of the world. In contrast, EnNahda's results are always below the average in France (1 and 2) and in the Americas/rest of Europe. Conversely, Map 3 shows that the results of Nidaa Tounes in 2014 are above the average in France and in Americas/rest of Europe, and below in the other constituencies (significantly below in Italy and close to the average in Germany and Arab countries/rest of the world).

The above shows that heterogeneity characterizes political preferences of Tunisian migrants in Western countries, while migrants in Gulf countries tend to vote for the Islamist party. In other words, Tunisian migrants socialized with liberal values in Western countries do not (always) tend to vote for "secular" parties that (supposedly) adhere to such values, nor they tend to reject the Islamist party that (supposedly) does not adhere to such values. Such observation suggests that migrants' political 


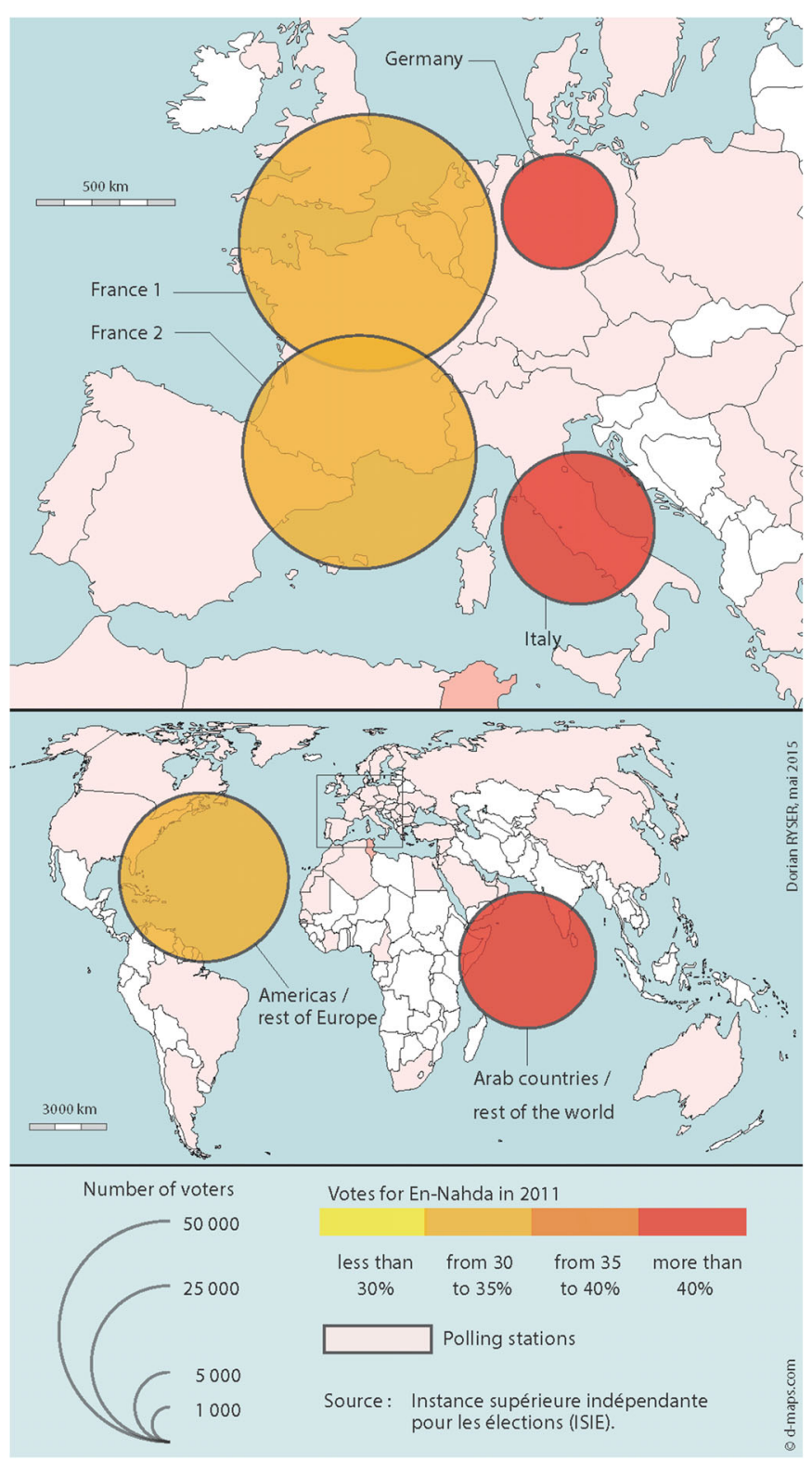

Map 1 Votes for EnNahda in the overseas constituencies in 2011

preferences are shaped prior departure. Contrasting voting trends among Tunisians in Italy and in North America can be explained by educational differences, as in Tunisia where the level of education is negatively to the vote for EnNahda (Gana et al., 2012). This conclusion calls for more research of migrants' transnational voting behaviour in light with the traditionnal migrants' preference for leftist parties in European elections (Brouard \& Tiberj, 2005; Rea, Dirk, Teney, \& Delwit, 2010) in order to understand the extent to which migrant communities can treat sending and receiving polities as entirely separate means.

In contrast to Western countries, greater homogeneity characterizes the voting behaviour of Tunisian migrants in the Gulf countries who are socialized with conservative values and who tend to vote for the Islamist party. One could thus argue that the 


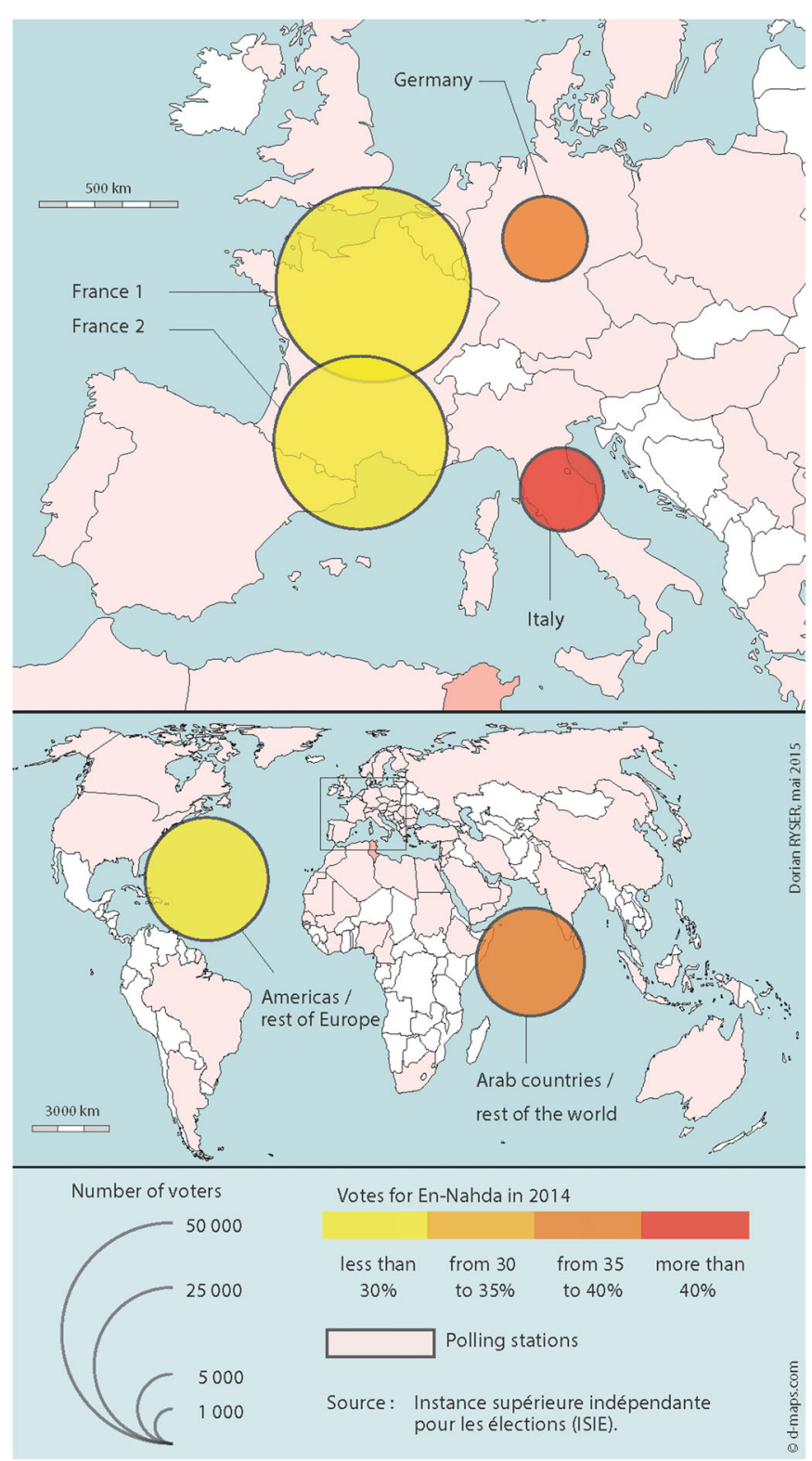

Map 2 Votes for EnNahda in the overseas constituencies in 2014

political and social regime of the host country have an influence on migrants' political preferences in authoritarian and conservative contexts, but not in democratic and liberal one's. However, political preferences of the Tunisians in the Gulf can also be explained by a self-selection bias: Tunisian individuals with conservative social and political values are more prone to migrate to the Gulf than their more liberal counterparts. Such hypothesis is partly confirmed by the very high results of EnNahda (above 60 \%) in medium-size cities of Oman and Saudi Arabia, in particular in Mecca and Medina, in contrast with larger metropolis of the Gulf, such as Dubai and Abu Dhabi, where the score of the Islamist party is below 50 \% (Jaulin, 2015).

The third level of analysis focuses on the French region of Île-de-France (Paris and suburbs). As mentioned above, two main reasons explain the choice of the Île-de- 


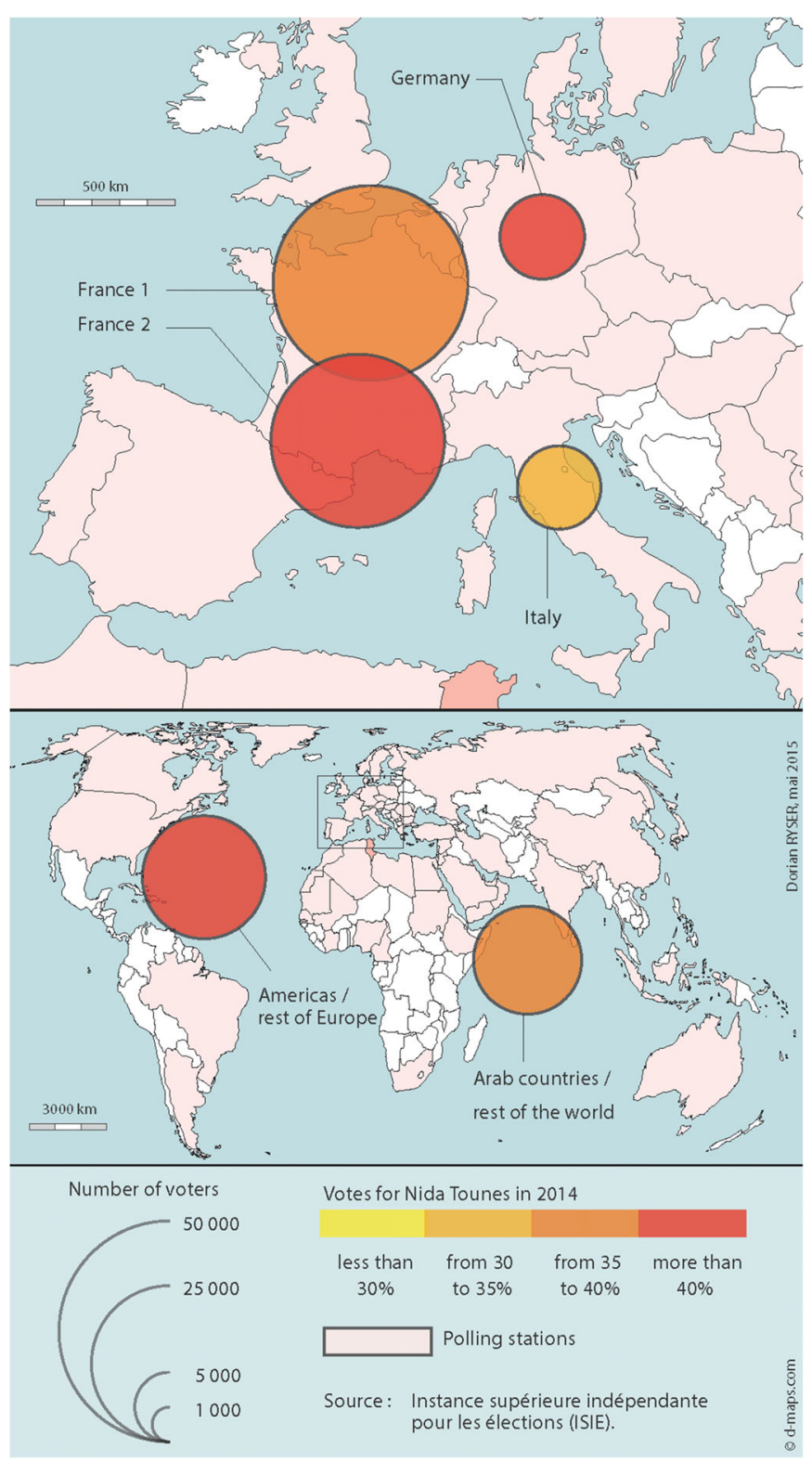

Map 3 Votes for Nidaa Tounes in the overseas constituencies in 2014

France as a case study to analyse the Tunisian voting behaviour at the local level. First, more than 50,000 Tunisians voted in the Île-de-France in 2011, that is to say about 80 $\%$ of the total number of voters in the constituency of France 1. Second, the local branch of the ISIE in the constituency of France 1 set up polling stations in about twenty different locations of the Île-de-France, both in Tunisian and French public buildings, ${ }^{19}$ which allows us to draw local electoral maps.

The following presents the results of EnNahda and Nidaa Tounes aggregated at the level of the eight districts of Île-de-France (departments): Paris (which is simultaneously a city and a district); the three districts of the inner suburbs (petite couronne: SeineSaint-Denis, Hauts-de-Seine, Val-de-Marne); and the four districts of the outer suburbs (grande couronne: Seine-et-Marne, Yvelines, Essone, Val d'Oise). Maps 4 and 5 compare 


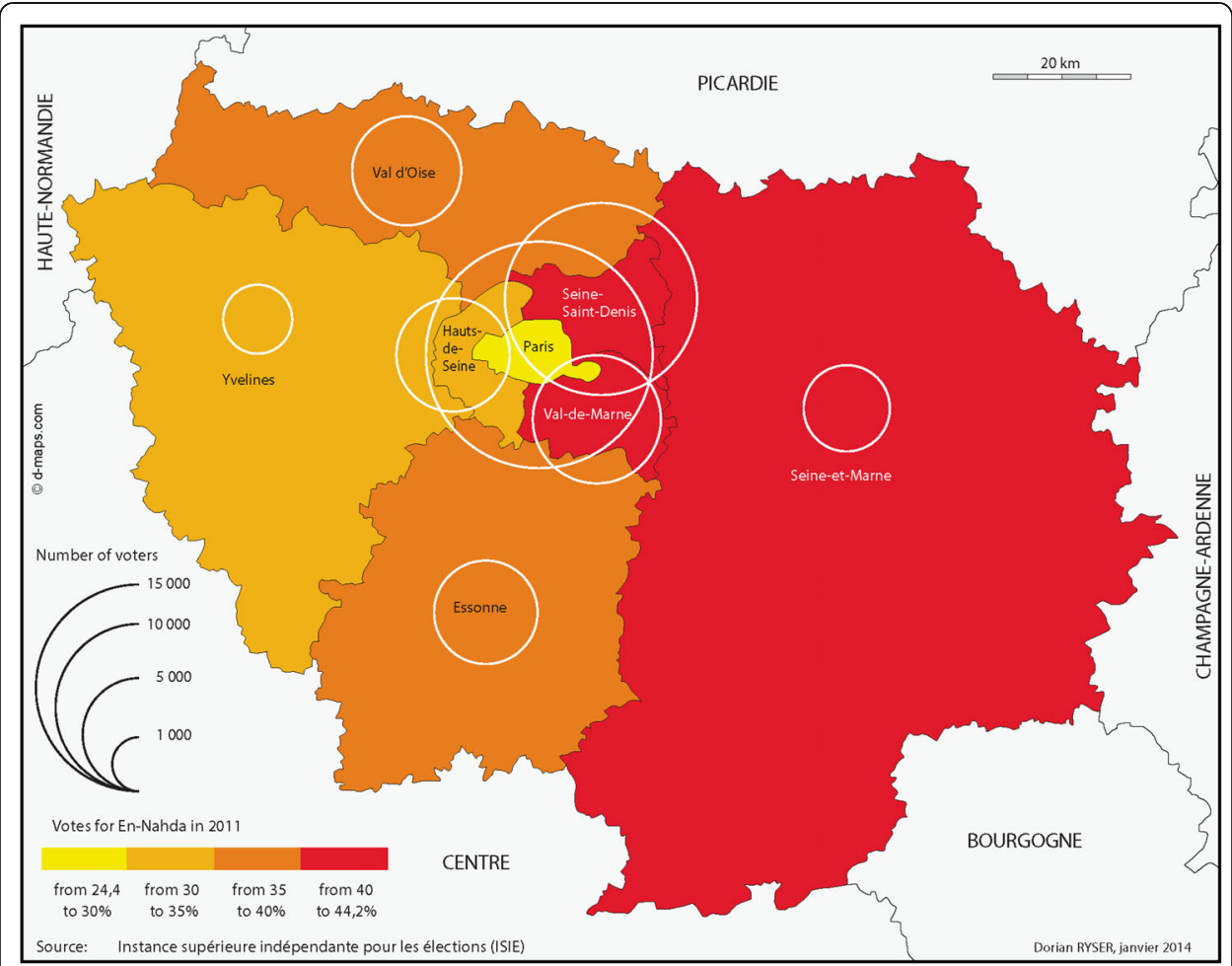

Map 4 Votes for EnNahda in the districts of Île-France in 2011

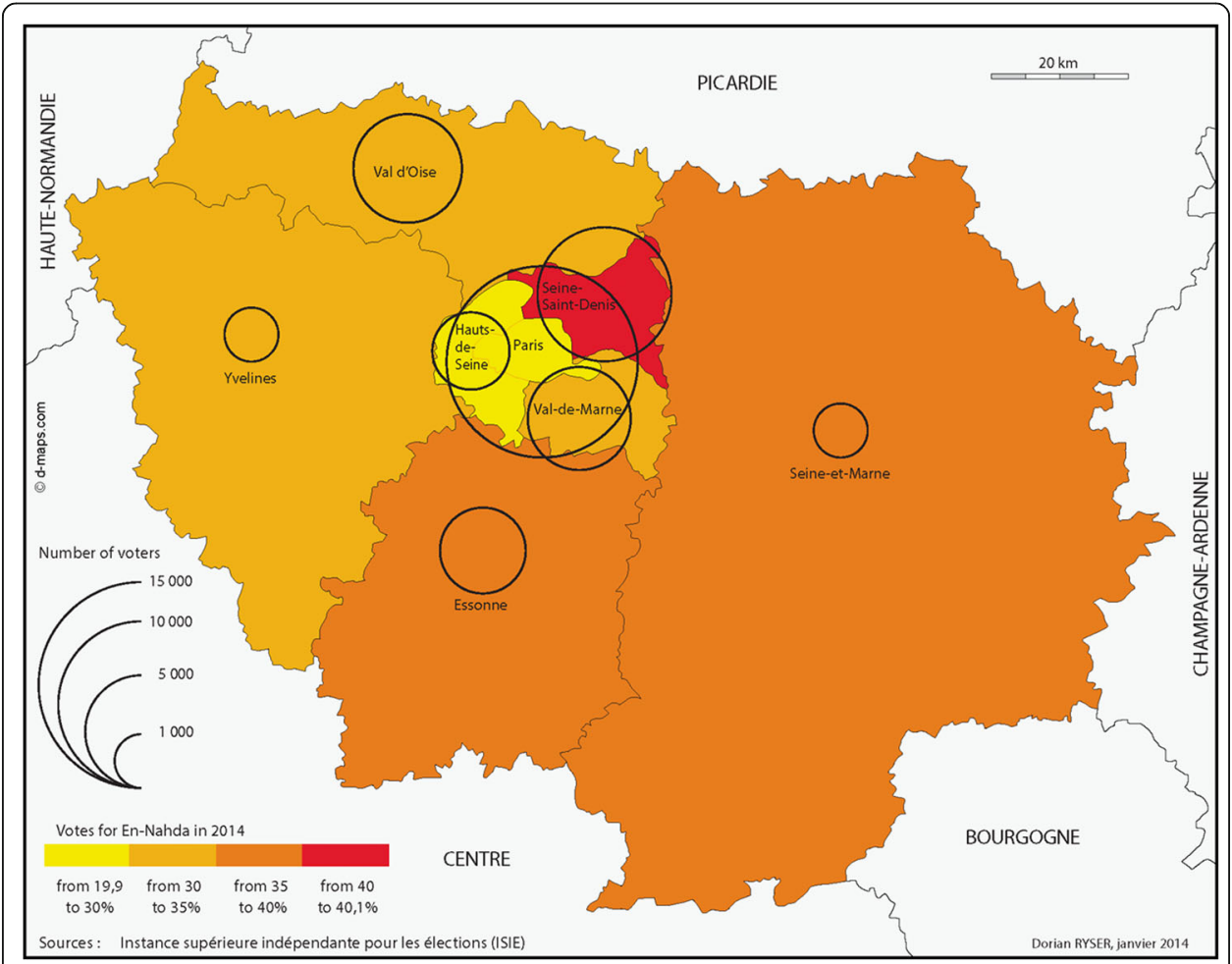

Map 5 Votes for EnNahda in the districts of Île-France in 2014 
the results of EnNahda in 2011 and 2014 in the Île-de-France, and Map 6 presents the results of Nidaa Tounes.

The geographic patterns of the Tunisian voting behaviour in the Île-de-France strikingly reflect entrenched territorial inequalities between Paris and the inner suburbs, and between the western and eastern districts (East/West) (Préteceille, 2009; Safi, 2009). Such finding fits with the hypothesis according to which the voters' socioeconomic background primarily influences their political preferences and that voting behaviour are strongly shaped prior departure.

However, such results also suggest to further exploring the extent to which the local context in which migrants are embedded has an influence on their electoral preferences. In other words, it calls for more research on community organizations, especially their history and ideological/political stances; their activities, territorial implementation and networks; and their potential support to a party or candidate during the electoral campaign. Eventually, it calls for more research on how family, friends and colleague contribute to shaping electoral participation and political preferences in a transnational context. In other words, to explore how mutual exchanges and influences among relatives at home and abroad influence the transnational elector's choice.

\section{Conclusion}

Tunisia represents a stimulating case study to discuss why and how States extend the franchise to non-resident citizens, and to explore patterns and dynamics of voter turnout and voting behaviour in external elections.

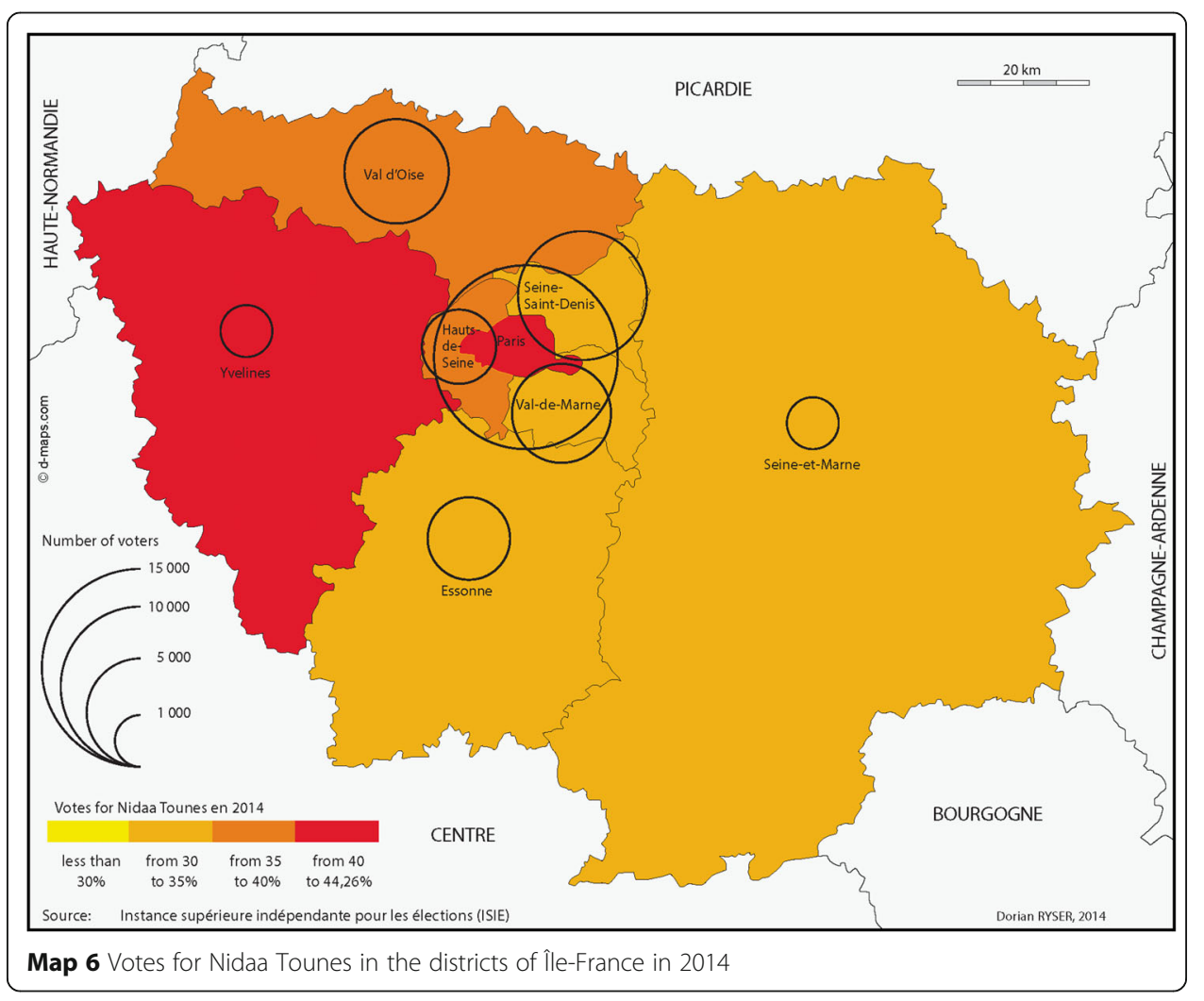


This paper first argues that the literature on external voting should pay more attention to the political context in which external voting provisions are adopted. Rather than focusing primarily on why States adopt external voting, more research studies should explore if and how external voting provisions are part of broader domestic processes of political change (authoritarian succession, regime consolidation, democratic transition). In addition, this paper calls for more research on the condition of implementation of external voting. More specifically, it suggests that the impact of voting procedures on the voter turnout is amplified in external elections due to the specific conditions under which the vote takes place.

This paper further discusses critically the idea according to which migrants socialised with liberal values in Western societies are expected to promote such values in their homeland. By doing so, it contributes to recent research studies according to which transnational political preferences are primarily shaped prior departure. The added value of this paper is twofold. First, it demonstrates the relevance of electoral mapping as a research tool to explore the formation of transnational political opinions and, more generally, migration patterns and social spaces of migration. Second, it suggests that transnational voting behaviour do not depend only on pre-migration variables and on self-selection bias, but also on the local context in which migrants are embedded (Escobar, Arana, \& McCann, 2016). Studying external voting behaviour may thus help us understanding the migrants' asymmetrical insertion in the receiving society, and the local processes of territorialisation.

\section{Endnotes}

${ }^{1}$ Lafleur and Sanchez Dominguez (2016) use a small-scale multi-sited exit poll survey to test the impact of pre-migration and post-migration variables. The former include demographic and socio-economic criteria, while the latter consist in the reason to migrate, the migration journey, the length of time abroad, and the living conditions in the host country (legal status, employment, experiences of discrimination, knowledge of the language, etc.).

${ }^{2}$ Political remittances represent a sub-category of social remittances, which encompasses ideas and practices conveyed by migrants convey between sending and receiving communities (Levitt, 1998).

${ }^{3}$ Quite few studies discuss transnational political dynamics among the Tunisians abroad. Studies that deal with political dynamics among Tunisian migrants tend to focus on political participation and activism in the host country (Brouard \& Tiberj, 2005; Wihtol de Wenden \& Leveau, 2007). The Tunisian Uprising in 2011 has spurred the development of new research studies on Tunisian transnational political activism, but most are on going. For examples see: "The role of Diasporas, Migrants and Exiles in the Arab Revolutions and Political Transitions", conference organized by WAFAW in partnership with the IREMAM and the IRMC, Tunis (National Library), $16^{\text {th }}$ and $17^{\text {th }}$ of October 2014. Moreover, the literature on Tunisian transnationalism includes studies that do not focus on political issues: Boubakri (1999) on migrants' entrepreneurship, Geisser (2000) on university graduates, Schmoll (2005) on women small traders, and Boubakri and Mazella (2011) on family networks. 
${ }^{4}$ In the 1990s and 2000s, the opposition to Ben Ali's regime in France bonded together Islamist activists and social and human rights activists, many of whom were former members of the Tunisian leftist student movement that developed in France in the 1970s.

${ }^{5}$ In French and Arabic at www.isie.tn

${ }^{6}$ Among various reasons that can explain such differences, destination countries' statistics (UNDESA figure) rarely include second-generation migrants and consular records (OTE figure) tend to be out-dated.

${ }^{7}$ The Democratic Modernist Pole (PDM), the Progressive Democratic Party (PDP).

${ }^{8}$ The Popular Petition for Freedom, Justice, and Development (AlAridha)

${ }^{9}$ The Congress for the Republic (CPR) of the former president of the Republic Moncef Marzouki and the Democratic Forum for Labour and Liberties (Ettakatol) of the former president of the Constituent Assembly Mustafa Ben Jaafar.

${ }^{10} \mathrm{~A}$ similar remark can be made for other criteria such as democratic/authoritarian, moderate/extremist, left/right, conservative/progressive.

${ }^{11}$ According to Simon (1979), the figure of Tunisians who migrated during this period is certainly higher, between 200,000 and 300,000 , due to the fact that seasonal migrants and naturalized migrants are not counted or counted separately.

${ }^{12}$ Libya represents an exception as UNDESA estimates the number of Tunisians in this country to 3000 while the figure of the OTE is close to 70000 . Such gap can be explained by the prevalence of circular migration due to the insecurity that prevails in Libya since 2011.

${ }^{13}$ The overseas constituencies of France 1 and France 2 roughly correspond to the two northern and southern halves of the country. Formally, Tunisians registered with the consulates of Paris, Pantin (Paris suburbs, in the district of Seine-Saint-Denis), and Strasbourg should vote in the constituency of France 1, and those registered with the consulates of Lyon, Marseille, Toulouse, Grenoble, Nice in the constituency of France 2.

${ }^{14}$ The number of voters per parliamentary seat is on average 14000 (current legislature). In overseas constituencies, this figure ranges from 2300 in Italy to 7800 in North America and rest of Europe. In Tunisia, it ranges from 8700 (Tozeur) to 26000 (Tunis).

${ }^{15}$ Interviews with Kamel Jendoubi, former head of ISIE (11 October 2013), Hazzem Ben Aissa, former member of ISIE in France (26 October 2012, Paris), Adnane Mokrani, former head of ISIE in Italy (15 October 2012)

${ }^{16}$ Interview with Mohammed Krir, former head of ISIE in France (16 September 2014)

${ }^{17}$ This figure was provided to the ISIE by the Ministry of Home Affairs in 2011, but we could not find an updated figure for 2014.

${ }^{18}$ For example, La Liste des associatifs de l'immigration tunisienne reached 22,6 \% and $16,8 \%$ of the votes in the polling stations of the cities of Angers and Le Mans, but less than $1 \%$ almost everywhere else.

${ }^{19}$ In Paris, polling stations were located at the embassy, the consulate and the cultural centre and in the city halls of the $11^{\text {th }}$ and $12^{\text {th }}$ arrondissements. In Seine-Saint-Denis, polling stations were located at the consulate of Pantin and the Tunisian cultural centre of Aubervilliers. In the other district of the region, polling stations were located in city halls: Asnières for the Hauts-de-Seine; Créteil for the Val-de-Marne; Sarcelles and Argenteuil for the Val-d'Oise; Melun, Meaux and Lognes for the Seine-et-Marne; Corbeil, Les Ulis, Epinay, and Massy for the Essonne; and Trappes for the Yvelines. 


\section{Competing interests}

The author declares no potential competing interest with respect to the research, authorship, and/or publication of this article.

\section{Authors' contribution}

Thibaut Jaulin is the sole author.

\section{Authors' information}

Thibaut Jaulin is a Marie Curie fellow at the CERI/Sciences Po (Paris) (thibaut.jaulin@sciencespo.fr).

\section{Acknowledgements}

The research for this paper was financially supported by the Research Executive Agency - European Commission. The author is grateful to Dorian Ryser (CERI/SciencesPo.) for his contribution to the design of the maps. The author thanks his friends and colleagues as well as two anonymous reviewers for their insightful comments on earlier version of this text.

Received: 16 September 2015 Accepted: 13 May 2016

Published online: 03 November 2016

\section{References}

Ahmadov, A., \& Sasse, G. (2015). Migrants' regional allegiances in homeland elections: evidence on voting by Poles and Ukrainians. Journal of Ethnic and Migration Studies, 41(11), 1769-1793.

Ayari, M. B. (2007-2008). Rester le même tout en devenant un autre: les «islamistes» tunisiens exilés en France [Stay the same while becoming another: the Tunisian "islamists" in exil in France]. Maghreb Machrek, 191, 55-69.

Bauböck, R. (2007). Stakeholder citizenship and transnational political participation: a normative evolution of external voting. Fordham Law Review, 75(5), 2393-2447.

Ben Mami, S. (2013). Les partis politiques tunisiens à la veille des élections législatives de juin 2013 [The Tunisian political parties on the eve of the June 2013 legislative elections]. Le Carnet de I'IRMC. http://irmc.hypotheses.org/ 848. Access on 25 June 2015

Bloemraad, I. (2013). The promise and pitfalls of comparative research design in the study of migration. Migration Studies, 1(1), 27-46.

Boubakri, H. (1999). Les entrepreneurs migrants d'Europe : dispositifs communautaires et économie ethnique. Le cas des entrepreneurs tunisiens en France [Migrant entrepreneur in Europe: community devices and ethnic economy. The case of the Tunisian entrepreneurs in France]. Cultures \& Conflits, 33-34.

Boubakri, H., \& Mazella, S. (2011). L'horizon transnational d'une famille tunisienne élargie The transnational horizon of an extended Tunisian family]. Autrepart, 1(57-58), 111-126.

Braconnier, C., \& Dormagen, J. Y. (2007). La démocratie de l'abstention [The democracy of abstention]. Aux origines de la démobilisation électorale en milieu populaire. Paris: Gallimard.

Brand, L. (2006). Citizen's abroad: emigration and the states in the Middle East and North Africa. Cambridge: Cambridge University Press.

Brand, L. (2010). Authoritarian states and voting from abroad. Comparative Politics, 43(1), 81-99.

Brédeloup, S., \& Pliez, O. (2011). Research Report Case Study EU-US Immigration Systems 2011/03. Robert Schuman Centre for Advanced Studies: European University Institute. The Libyan Migration Corridor.

Brouard, S., \& Tiberj, V. (2005). Français comme les autres? [French as others?]. Paris: Les presses de Sciences Po.

Burean, T. (2011). Political participation by the Romanian Diaspora. In P. E. Sum \& R. F. King (Eds.), Romania under Băsescu (pp. 83-105). Lexington: Lanham.

CARIM. (2010). Tunisia migration profile. Robert Schuman Centre for Advanced Studies: European University Institute.

Ferjani, MC. (2012). Révolution, élections et évolution du champ politique tunisien [Revolution, elections, and evolution of the Tunisian political landscape]. Confluences Méditerranée, 3(82), 107-116.

Chouikha, L. (2012). L'Instance Supérieure Indépendante pour les Elections et le processus électoral tunisien: un témoignage de l'intérieur The Higher Independant Body for the Elections and the Tunisian electoral process: a testimony from the inside]. Confluences Méditerranée, 3(82), 171-185.

Collyer, M. (2014). Inside out? Directly elected 'special representation' of emigrants in national legislatures and the role of popular sovereignty. Political Geography., 41, 64-73.

Collyer, M., \& Vathi, Z. (2007). Patterns of Extra-territorial Voting. Working paper, T22, Development Research Centre on Migration, Globalisation and Poverty.

Dedieu, J.P., Chauvet, L., Gubert, F., Mesplé-Somps, S., \& Smith, E. (2013). Les 'batailles' de Paris et de New York. Une analyse du comportement électoral transnational des migrants sénégalais en France et aux États-Unis [The "battles" of New York and Paris. An analysis of the transnational electoral behaviour of Senegalese migrants in France and the United States]. Revue française de science politique, 63(5), 865-892.

Escobar, C., Arana, R., \& McCann, J. (2016). Expatriate voting and migrants' place of residence: explaining transnational participation in Colombian elections. Migration Studies, 49(1), 78-114.

Fargues, P. (Ed.). (2005). Mediterranean migration 2005 Report. European University Institute. Robert Schuman Centre for Advanced Studies.

Fargues, P. (2012). Demography, migration and revolt in the Southern Mediterranean. In C. Merlini \& O. Roy (Eds.), Arab society in revolt. The West's Mediterranean challenge (pp. 17-46). Washington D.C: Brookings Institution Press.

Gana, A., Van Hamme, G., Ben Rebah, M. (2012). Géographie électorale et disparités socioterritoriales: les enseignements des élections pour l'assemblée constituante en Tunisie [Electoral geography and socioterritorial inequalities: conclusions from the elections for the Constituant Assembly in Tunisia]. L'Espace politique, 3(18).

Geisser, V. (Ed.). (2000). Diplômés maghrébins d'ici et d'ailleurs. Trajectoires sociales et itinéraires migratoires [North African university graduates from here and there. Social trajectories and migration itineraries]. Paris: CNRS Edition. 
Geisser, V. (2012). Quelle révolution pour les binationaux ? Le rôle des Franco-Tunisiens dans la chute de la dictature et dans la transition politique [Which revolution for the binationals? The role of Franco-Tunisians in the fall of the dictatorship and the political transition]. Migrations Société, 24(143), 155-178.

Institut national de la statistique et des études économiques (INSEE). (2012). Résultats statistiques du recensement [Statistical results of the census]. http://www.insee.fr Access of 25 June 2015

International IDEA. (2007). Voting from abroad. The International IDEA Handbook. Stockholm and Mexico: International IDEA and The Federal Electoral Institute of Mexico.

Jaulin, T. (2015). The geography of external voting: the 2011 Tunisian election abroad, transnational study initiative working paper, no 1. Harvard: University.

Koinova, M. (2010). Diasporas and international politics: utilizing the universalistic creed of liberalism for particularistic and nationalist purposes. In R. Bauböck \& T. Faist (Eds.), Diaspora and transnationalism: concepts, theories and methods (pp. 149-160). Amsterdam: Amsterdam University Press.

Lafleur, J. M. (2013). Transnational politics and the state. The external voting rights of Diaspora. New York and London: Routledge.

Lafleur, J. M. (2015). The enfranchisement of citizens abroad: variations and explanations. Democratization. 22(5), 840860.

Lafleur, J. M., \& Sanchez Dominguez, M. (2016). The political choices of emigrants voting in home country elections: a socio-political analysis of the electoral behavior of Bolivian external voters. Migration Studies, 49(1), 78-114.

Levitt, P. (1998). Social remittances: migration driven local-level forms of cultural diffusion. International Migration Review, 32(4), 926-948.

Lieckefett, M. (2012). La Haute Instance et les élections en Tunisie: du consensus au 'pacte politique'? [The Higher Body and the elections in Tunisia: from consensus to "political agreement"?] Confluences Méditerranée, 3(82), 133-144.

Lopez-Guerra, C. (2005). Should Expatriates Vote? The Journal of Political Philosophy, 13, 216-234.

Mahmoud, T., Rapoport, H., Steinmayr, A., \& Trebesch, C. (2013). The effect of labor migration on the diffusion of democracy: evidence from a former soviet republic. Kiel working paper, $n^{\circ} 1869$

Mourakiboun. (2014). Rapport final des élections législatives et présidentielles de 2014 [Final report on the 2014 legislative and presidential elections]. http://www.mourakiboun.org. Accessed on 25 June 2015

Office des Tunisiens à l'étranger (OTE). (2012). Données statistiques. Répartitions des tunisiens à l'étranger [Statistical data. The repartition of the Tunisians abroad]. http://www.ote.nat.tn. Accessed on 1 June 2015

Oueslati, A. (2009). Les Tunisiens en France, 40 ans après: nouvelle photographie et dynamique spatiotemporelle [Tunisians in France 40 years later: new photography and spatio-temporal dynamics]. In G. Dubus \& A. Oueslati (Eds.), Regards sur les migrations tunisiennes (pp. 13-32). Agadir: Editions Sud Contact.

Préteceille, E. (2009). La ségrégation ethno-raciale dans la métropole parisienne [Ethnoracial segregation in the metropolitan area of Paris]. Revue française de sociologie, 50(3), 489-519.

Rea, A., Dirk, J., Teney, C., \& Delwit, P. (2010). Les comportements électoraux des minorités ethniques à Bruxelles. [Electoral behaviour of ethnic minorities in Brussels]. Revue française de science politique, 60(4), 691-717.

Rhodes, S., \& Harutyunyan, A. (2010). Extending citizenship to emigrants: democratic contestation and a new global norm. International Political Science Review, 31(4), 470-493.

Rowe, P. (2001). Four guys and a fax machine? diasporas, New information technologies, and the internationalization of religion in Egypt. Journal of Church and State, 43(1), 81-92.

Rubio-Marin, R. (2006). Transnational politics and the democratic nation-state: normative challenges of expatriate voting and nationality retention of emigrants. New York University Law Review, 81, 117-147.

Safi, M. (2009). La dimension spatiale de l'intégration des populations immigrées (1968-1999) [The spatial dimension of the integration of immigrant populations (1968-1999)]. Revue française de sociologie, 50(3), 521-552.

Schmoll, C. (2005). Pratiques spatiales transnationales et stratégies de mobilité des commerçantes tunisiennes [Transnational spatial practices and mobility strategies of Tunisian tradeswomen]. Revue européenne des migrations internationales, 21(1).

Simon, G. (1979). L'espace des travailleurs tunisiens en France. Structure et fonctionnement d'un champs migratoire international [The spaces of Tunisian labourers in France. Structure and operation of an international migration field]. Poitiers: Gildas Simon.

Sliman, L., \& Khlif, W. (2009). Les compétences tunisiennes à l'étranger: peut-on parler d'une diaspora scientifique? [The Tunisian skills abroad: a scientific diaspora?] L'Année du Maghreb, 5, 421-436.

United Nation Department of Economic and Social Affairs (UNDESA). (2010). Population Division. Migration Section. International Migration Stock. http:/www.un.org/en/development/desa/population/migration/index.shtml. Accessed on 25 June 2015

Verdeil, E. (2012). La participation aux élections tunisiennes: un regard géographique [The participation to the Tunisian elections: a geographic perspective]. Rumor. http://rumor.hypotheses.org/2277. Accessed on 25 June 2015

Wihtol de Wenden, C., \& Leveau, R. (2007). La Beurgeoisie [The Beurgeoisie]. Paris: CNRS Editions. 